\title{
Paediatric neuropathology: Diagnosis
}

\author{
S K Misser, MB ChB, FCRad (D)
}

Lake Smit and Partners, Durban

J F Roos, MB ChB, MMed (Paed)

Parklands Hospital, Durban

Corresponding author: S Misser (shalendramisser@hotmail.com)

Please refer to page 101 of the September 2011 issue of the SAJR (also available online at http://www.sajr.org.za/index.php/sajr/article/ view/610/459) for the presentation details. We congratulate Dr S Moosa (Department of Radiology, 2 Military Hospital, Wynberg, Cape Town) for a well-researched and comprehensive diagnosis, for which he receives an award of R1 000 from the RSSA. Dr Misser elaborates below on the condition and its imaging.

\section{Presentation and diagnosis}

(Because of space constraints, the images referred to below are not reproduced here but are in the September 2011 issue of the SAJR and online at the above URL.)

The patient presented here was a 10-month-old girl, delivered pre-term by caesarean section, with a birthweight of $2.4 \mathrm{~kg}$ and good Apgar scores. In her first year, she was treated for gastrooesophageal reflux and had one life-threatening episode of refluxassociated apnoea with aspiration pneumonia. Fundoplication surgery was succesfully performed. In the late neonatal period, progressive loss of neurological milestones was observed. Baseline and preliminary special investigations(including chromosomal analysis, lacate and pyruvate) were non-contributory.

On visual testing, cortical blindness was suspected. Hearing was normal. The paediatric neurologist noted marked irritability and exaggerated response to basic stimuli, prompting further testing. MRI scan showed marked generalised cerebral atrophy and proportional ventriculomegaly. T2-weighted high signal was noted extensively in the white matter, thalami and basal ganglia, with relative sparing of the U-fibres. Inversion recovery sequence showed reduced ventral pontine signal, sparing the transverse pontine fibres. After gadolinium administration, symmetrical cranial nerve enhancement was demonstrated of the optic, oculomotor and trigeminal nerves. Questionable focal enhancement was noted at the left brachium pontis (Fig. 4b). Serum galactocerebrosidase levels were found to be very low, confirming suspected Krabbe leucodystrophy.

\section{Discussion}

White matter disease in childhood is broadly classified as demyelinating or dysmyelinating. The dysmyelinating diseases, or leukodystrophies, result in abnormal production and breakdown of myelin. These are usually caused by an enzyme deficiency and are best sub-divided based on the cellular organelle involved. ${ }^{1}$ See Table I.

Krabbe disease, or globoid cell leukodystrophy, is a neurodegenerative illness of infancy, with 4 clinical subtypes, distinguished by age of onset viz. infantile, late infantile, juvenile and adult. It is an autosomal recessive disorder, with the gene fault mapped to chromosome 14, resulting in deficiency of galactocerebroside- $\beta$-galactosidase. This enzyme degrades cerebrosides, a normal constituent of myelin. Accumulation of cerebrosides in the lysosmes of macrophages results in formation of globoid cells, typical of this disease. Clinically, the infantile subtype is the most common, manifesting with irritability, progressive spasticity,

Table I. White matter diseases according to cellular organelle involved

\begin{tabular}{|c|c|c|c|}
\hline $\begin{array}{l}\text { Lysosomal storage } \\
\text { diseases with white } \\
\text { matter involvement }\end{array}$ & Peroxisomal disorders & $\begin{array}{l}\text { Mitochondrial dysfunction } \\
\text { with leukoencephalopathy }\end{array}$ & $\begin{array}{l}\text { Other white matter } \\
\text { dysmyelinating disorders }\end{array}$ \\
\hline $\begin{array}{l}\text { Metchromatic } \\
\text { leukodystrophy }\end{array}$ & Zellweger syndrome & Leigh disease & Canavan disease \\
\hline Krabbe disease & X-Linked adrenoleukodystrophy & MELAS & Alexander disease \\
\hline Niemann-Pick disease & $\begin{array}{l}\text { Neonatal adrenoleukodystrophy } \\
\text { (ALD) }\end{array}$ & MERRF & $\begin{array}{l}\text { Congenital muscular } \\
\text { dystrophy (Fukuyama) }\end{array}$ \\
\hline Fabry disease & Pseudoneonatal ALD & & \\
\hline $\begin{array}{l}\text { GM1 and GM2 } \\
\text { gangliosidosis }\end{array}$ & Classic Refsum disease & & Pelizaeus-Merzbacher disease \\
\hline \multicolumn{4}{|l|}{ Mucopolysaccharidosis } \\
\hline \multicolumn{4}{|l|}{ Fucosidosis } \\
\hline \multicolumn{4}{|l|}{ Mucolipidosis } \\
\hline \multicolumn{4}{|l|}{ Wolman disease } \\
\hline Ceroid lipofuscinosis & & & \\
\hline
\end{tabular}


blindness, dysphagia, mental deterioration and milestone regression.

MRI has been shown to play a fundamental role in diagnosis and follow-up imaging of children with Krabbe's disease. Provenzale et al. ${ }^{2}$ showed good correlation of MRI findings (using Loes scores ${ }^{3}$ ) with clinical scoring systems. Centrum ovale, basal ganglia, thalami, internal capsule, cerebellum and brainstem are all areas that demostrate T2 and FLAIR sequence hyperintensity. Thalamic involvement is a useful sign to differentiate from metachromatic leukodystrophy. ${ }^{4}$ Optic nerve hypertrophy and/or enhancement, as well as enhancement of other cranial nerves, is a feature of the disease. ${ }^{5}$ Severe progressive atrophy, involvement of U-fibres, cortical blindness and seizures are usually late phenomena. Diagnosis is made by detecting enzyme deficiency in leukocytes or cultured skin fibroblasts. Treatment includes bone marrow transplantation, supportive therapy and physiotherapy.

1. Cheon J, Kim IO, Hwang YS, et al. Leukodystrophy in children: A pictorial review of MR Imaging features. RadioGraphics 2002;22:461-476.

2. Provenzale JM. Correlation of neurodevelopmental features and MRI findings in infantile Krabbés disease. AJR 2009;192:59-65.

3. Loes DJ, Hite S, Moser H, et al. Adrenoleukodystrophy: a scoring method for brain MR observations. AJNR 1994;15:1761-1766.

4. Candy S. An Approach to White and Grey Matter Disease in Children. In: Baby Steps into Paediatric Neuroradiology. Andronikou S, Wieselthaler N, Kader E (eds). 1st ed. Pretoria: SAMA Press, 2004

5. Jones BV, Barron TF, Towfighi J. Optic nerve enlargement in Krabbe’s disease. AJNR 1999;20:1228-1231.

\section{Paediatric vascular imaging}

\section{S K Misser, MB ChB, FCRad (D) SA}

Lake Smit and Partners, Durban

J N Narsai, MB ChB, FC Paed SA

Crompton Hospital, Durban

Corresponding author: S Misser (misser@lakesmit.co.za)

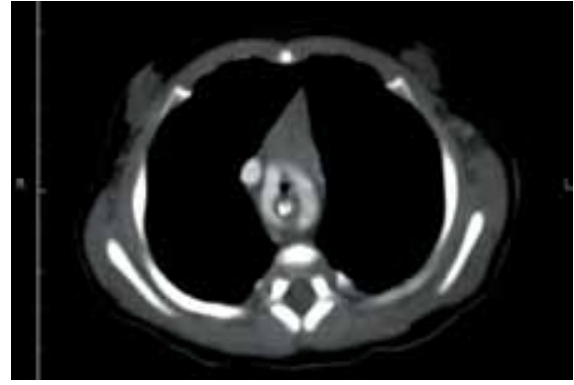

Fig. 1.

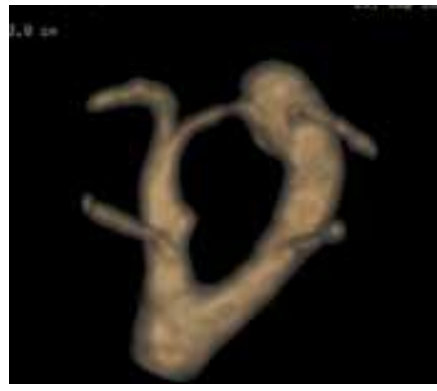

Fig. 4.

\section{Presentation}

An early neonate presented with stridor, and the following images were obtained. Figs 1 and 2 are axial post-contrast CT angiogram images at the level of the aortic arch. Note a nasogastric tube in situ. Figs 3 and 4 are volume-rendered $3 \mathrm{D}$ reconstructions of the $\mathrm{CT}$ angiogram from the level of the aortic root to the great vessels. Fig. 5 is a coronal reformatted image through the abdomen. Fig. 6 is a virtual bronchoscopy image of the tracheobronchial tree.

Fig. 2.

Fig. 5.
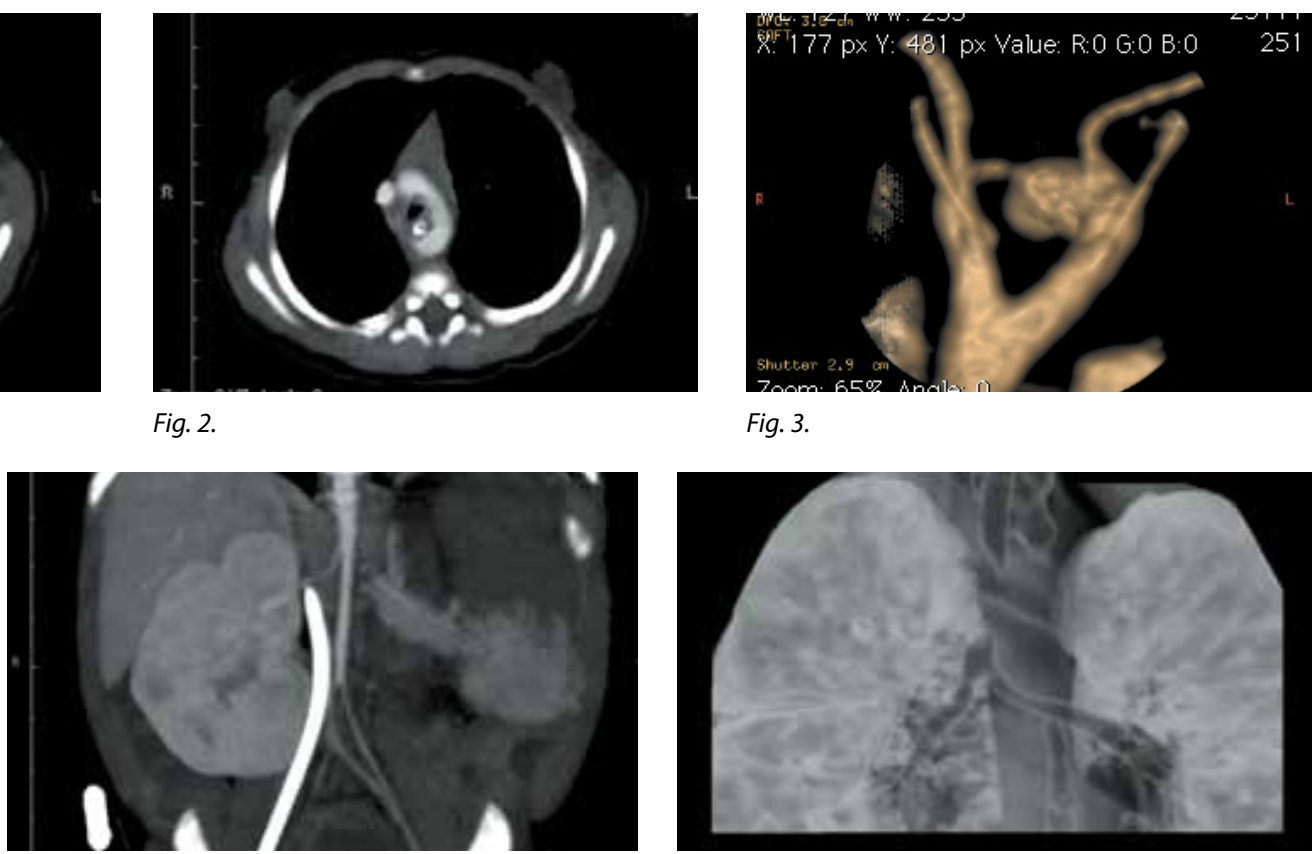

Fig. 3.

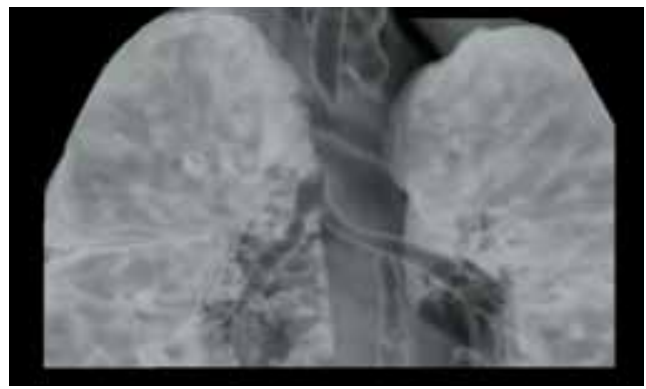

Fig. 6.

Describe the relevant findings and provide the most appropriate clinical diagnosis. Please submit your response by email to Dr Misser at misser@lakesmit.co.za not later than 1 February 2012. The winning respondent will receive a R1 000 award from the RSSA. A detailed diagnosis and discussion will be presented in the next SAJR. 